\title{
Global economic fluctuations and human development: how is the impact transmitted in Egypt?
}

\author{
Amira Mohamed Emara
}

Department of Economics and Foreign Trade, Faculty of Commerce and Business Administration, Helwan University, Cairo, Egypt, and

Nashwa Mostafa Ali Mohamed

Department of Economics, King Saud University, Riyadh, Saudi Arabia and Department of Economics and Foreign Trade, Faculty of Commerce and Business Administration, Helwan University, Cairo, Egypt

\begin{abstract}
Purpose - This paper aims to investigate the relationship between global economic fluctuations and human development through four transmission channels (foreign direct investment (FDI), official development aid (ODA), remittances and export earnings) in Egypt as an open developing economy, in the period 1990-2015.

Design/methodology/approach - The paper uses a vector autoregressive model, which implies examining the impulse response functions and variance decompositions.

Findings - The results indicate that human development is negatively affected by global economic fluctuations through the four channels, namely, ODA, FDI, export earnings and remittances. In addition, the most effective transmission channels are FDI in the short run and export earnings in the long run.

Originality/value - While a large body of literature addresses the direct impact of business cycles and economic shocks on human development, only some studies focus on the indirect impact. The contribution is to identify the indirect impact of global economic fluctuations on human development in a developing economy, considering four transmission channels and to determine the most important of these channels. Moreover, using the human development index is an addition in this paper as most previous literature depends on other human development indicators such as children's health, employment and schooling.
\end{abstract}

Keywords Egypt, MENA, Human development, VAR model, Global economic fluctuations, Transmission channels

Paper type Research paper

\section{Introduction}

According to business cycles literature, economic activities expand and contract around a long-term growth trend, having four distinct phases, namely, expansion, peak, contraction and trough, following the upward and downward movement of the growth rates of real gross domestic product (GDP), real income, employment and industrial production. Financial crises are considered one of the main driving forces of business cycles. During the

(C) Amira Mohamed Emara and Nashwa Mostafa Ali Mohamed. Published in Review of Economics and Political Science. Published by Emerald Publishing Limited. This article is published under the Creative Commons Attribution (CC BY 4.0) licence. Anyone may reproduce, distribute, translate and create derivative works of this article (for both commercial and non-commercial purposes), subject to full attribution to the original publication and authors. The full terms of this licence maybe seen at http://creativecommons.org/licences/by/4.0/legalcode

Received 24 June 2020 Revised 13 October 2020 Accepted 2 December 2020 
1990s, the world has witnessed many financial crises that arose in emerging and Asian countries; and in 2008 the USA was hit by a major financial crisis, which cast a shadow on the whole world. The intensity of the effect of an economic crisis varies and may depend on the economic power of the country where it originates and the resulting capital inflows and outflows. Because of its growing economy, China has become one of the main actors in the world economy and to express its global impact sometimes it is said that if China sneezes, the world catches the flu. This was evident during the recent economic recession, in 2015, which was induced by the change of China's economic growth model, from trade-led growth to consumption-led growth and resulted in a decline in China's demand for imported inputs and fuels, causing a reduction in world trade and investments (IMF, 2015).

Acceleration and deceleration growth have significant impacts on the human development indicators, whereas the negative impact of deceleration overcomes the positive one of acceleration (Bedir, 2015). In a global open economy, the growth slowdown of the main players spreads broadly to the rest of the world through international finance. A downturn in their economies leads to a shortfall in their capability to send money flows to developing countries. The transmission channels of these flows are represented in aids, revenues of commodity exports and tourism, remittances and inward investments. Through all or some of these channels, global economic fluctuations affect the income of developing countries (Habib et al., 2010), which, in turn, finances household spending on the consumption of nutritious food, investment in education and health care. The expected negative effect of global economic fluctuations on human development in affected countries may not happen if it is compensated by household withdrawals from their savings or by governmental support. On the other hand, the accelerating internal inflation rates and the decreasing inflows of foreign aids and investments may reinforce the adverse effect. In light of the above, this paper attempts to investigate how global economic fluctuations affect human development in a developing economy through the four mentioned transmission channels.

The main motivation of studying this relationship is to identify the reasons behind the deterioration of Egypt's ranking in the human development index (HDI), which was 111 out of 188 in 2015, in spite of the increasing trend of HDI over the period 1990-2015. Because Egypt is considered an open developing economy, its HDI is probably affected by external economic fluctuations. In addition, determining the relative importance of transmission channels would be a good guidance for policymakers in designing suitable economic policies and developing procedures to reduce adverse effects and benefit from positive effects. Therefore, this paper seeks to answer the following questions:

- What is the effect of global economic fluctuations on human development in Egypt?

- What are the most important transmission channels of these fluctuations?

- How could Egypt achieve progress in HDI ranking?

- How can policymakers benefit from the results?

To address these questions empirically, the paper's methodology depends on a vector autoregressive model (VAR). As time-series stationary is a necessary prerequisite to estimate the VAR model, a unit root test will be conducted (Boheman and Maxén, 2015). In addition, the VAR analysis implies examining the impulse response functions and variance decompositions. Economic fluctuations will be calculated as the volatility in the world annual growth rate of GDP by using ARCH-GARCH. Data of the variables covers the period 1990-2015 and is obtained from the World Bank (World Development Indicators), except for 
HDI, which is available from the Human Development Report, issued by the United Nations Development Program (UNDP).

Despite the large body of literature on the direct impact of business cycles and economic shocks on human development (Duryea et al., 2007), only some studies focused on the indirect impact of foreign aids of donor countries, as a transmission channel of their economic crises, on poverty or human capital in recipient countries (Pallage and Robe, 2001; de Sousa, 2010; Dang et al., 2013) and few extended the analysis to investigate additional channels, such as foreign direct investments (FDIs) and export earnings, on the GDP of one developing economy (Kazi, 2014) or on human development of a group of developing economies (Conceição and Kim, 2009). Therefore, our contribution is to identify the indirect impact of global economic fluctuations on human development in a developing economy, considering four transmission channels and to determine the most important of these channels. Moreover, using the HDI is an addition in this paper as most previous literature depended on other human development indicators such as, children's health, employment and schooling (Paxson and Schady, 2005; Duryea et al., 2007; Oryoie and Alwang, 2018).

The remainder of the paper is organized as follows: Section 2 briefly reviews the previous literature. Section 3 gives an overview on human development in Egypt. Section 4 describes the methodology, variables, data sources and the model. Section 5 presents empirical results and discussion. Section 6 provides the conclusion and policy implications.

\section{Background and literature review}

Economic fluctuations are caused by internal or external shocks, which cause crises. Many previous studies have investigated the impact of global economic fluctuations through their transmission channels on various economic variables (Schmitt-Grohé,1998; Pallage and Robe, 2003). One of these variables is human development, which is affected by crises in two contradictory ways. On one side, crises may positively affect the rate of school enrollment and graduation because of the declining opportunity cost of dropping out of school as a result of decreased employment opportunities and low indicators of the economic activities that accompany financial crises (Goldin, 2001; McKenzie, 2003; Black and Sokoloff, 2006). On the other side, financial crises usually synchronize with fluctuations of economic growth and employment, which, in turn, affect human development indicators. Crises may cause a collapse in household income, as well as, both public and private spending on health care, leading to an increase in infant mortality rates (Paxson and Schady, 2005). This adverse effect differs between acceleration and deceleration periods and is stronger and shorter in the last one. Using per capita growth rate and human development indicators for 131 countries between 1974 and 2007, Bedir (2015) found that growth acceleration and deceleration have significant impacts on the human development indicators, and that the negative impact of deceleration exceeds the positive impact of acceleration. This result complies with the findings of Conceição and Kim (2009). It is worth mentioning that returning to the original levels of employment and unemployment rates after a crisis, from the trough to the peak, may take a longer time than the movement from the peak to the trough of the economic cycles (De Beer, 2012).

As mentioned above, the most affected sector in the economy is households, especially if the economy is labor-intensive. Households suffer from a decline in their income because of changes in government spending, job losses, low wages and falling profits from selfemployment. Although according to the hypothesis of permanent income, households may sustain the level of human development by maintaining the consumption of other goods and services by drawing upon previous reserves, selling assets, accessing credits or remittances from relatives abroad. As this will coincide with increasing demand for public services of 
health, education and social protection, this hypothesis may not be acceptable in case of insufficient available finance, falling public revenues and reduction in official development assistance (ODA) (Conceição and Kim, 2009).

Regarding the relationship between household income and human development indicators, many studies (Jacoby and Skoufias, 1997; Duryea et al., 2007; Ferreira and Schady, 2009; Friedman and Schady, 2009) conclude that increases in poverty rates and infant mortality, besides decreases in health and education outcomes, often accompany economic crises, fluctuations in national income, per capita GDP, wages, employment and prices. Furthermore, economic crises affect household income through an overall loss of jobs and wages, depreciation of the domestic currency, which, in turn, raises the cost of imports and foreign debts and decreases the earnings from foreign investments and exports. Consequently, tax revenues and fiscal spending on education and health budgets will be diminished, causing income inequality within the country, especially for wage-earners and those who depend intensively on public social services (Miller, 2005). In this context, the results of Levin and Raut (1997) indicate a high degree of complementarity between export earnings and education expenditures in semiindustrialized countries. Applying on Bangladesh, Mexico, Philippines, Egypt, Mangolia and Poland, Habib et al. (2010) found that financial crisis has important impacts on poverty and income distribution, where some regions and income groups suffer more than others in the same country.

Most of the mentioned previous studies addressed the impact of crises, on some indicators of human development, regardless of where the first spark of the crisis has started, whether from inside or outside the economy. In examining the effects of global economic fluctuations, we have to consider that a crisis often spreads out from one country to other countries by contagion. Loss of employment and labor income, that accompanies crises, restricts the financial capability of the country, where the crisis has started. It is unable to send capital outflows, remittances, pay for imports or even donate ODA. Therefore, international finance is pro-cyclical, where it often decreases during recessions and increases during expansions (Panizza, 2001; El Husseiny, 2018). Thus, human development programs in the receiving country will be affected by this shortage in earnings, which are usually used to fund them. Furthermore, crisis management may add more burdens on the capability of the country to sustain social expenditure and human development, if it depends on external debt to finance budget deficits (Miller, 2005).

A body of empirical literature considered the transmission channels of the impact of global economic fluctuations on a lot of economic indicators in the recipient countries. Concentrating on three channels, namely, aids, FDI and export earnings, for the Tanzanian economy, Kazi (2014) found that foreign aid is more important than other transmission channels of the global crisis, followed by export revenues. Using panel data from 24 donor countries during the period from 1977 to 2007, Dang et al. (2013) found a fall in aid flows, by an average of $20 \%$ to $25 \%$, associated with banking crises in donor countries. When a crisis begins in wealthy countries, donors decrease aid flows to developing countries, not only because the income of donor-country falls but also because of the high fiscal costs of the banking and financial sector. However, recipient countries may face less aid volatility if they are characterized with efficient financial markets, institutional quality and macroeconomic stability and depend on a large variety of donors rather than relying on a few donors (Fielding and Mavrotas, 2008; Kumi et al., 2017). Nevertheless, other studies have found no correlation between aid and the recipient's output (Pallage and Robe, 2001) or even an evidence that aid, in the shape of ODA, guarantees improving human development (Goldin et al., 2002). Likewise, El-Sholkamy (2016) concluded that in the absence of the institutional 
quality, the more foreign aid African Governments have received, the more their governance has deteriorated. It is worth mentioning that most of the related literature focused only on aid inflows as a transmission channel of output fluctuations from donor countries to recipient ones, but did not give the same attention to address its effect on human development indicators.

In contrast to the co-movement of aid and business cycles, remittances are less volatile and relatively stable even during sharp increases in volatility, thus, it can help to promote consumption stability during global economic fluctuations (De et al., 2016). Appling on SubSaharan Africa during the period 1987-2007, Adenutsi (2010) concluded that remittances have a positive impact on human development in the long run, while Ponce et al. (2008) found no evidence for this result in Ecuador. Although Ustubici and Irdam (2012) agreed on the positive correlation between remittances and human development, it found that the developmental effects depend on the country's government approaches to migration, considering the most positive effect of remittances to be where the governments regard migration as an effective labor export strategy. In addition, Shirazi et al. (2018) evaluated the effect of remittance inflows on economic growth and poverty for seven member countries of the Organization of Islamic Cooperation. Their study used a simultaneous equation model and found that the increased flows of remittances improve the purchasing power of the poor, increase the level of consumption, reduce poverty and build infrastructure and human capital (Shirazi et al., 2018).

Regarding FDI, it positively impacts human development through its contribution to economic growth and export earnings of the host country. Furthermore, it promotes technology transfer, which, in turn, raises production efficiency, and improves quality. However, several studies concluded that FDI has only a small effect on human development (Sharma and Gani, 2004; Reiter and Steensma, 2010; Lehnert et al., 2013; Pérez-Segura, 2014). This may be attributed to the lack of diversification of FDI received in the economy. Accordingly, Soumaré (2015) found that FDI received by North African countries may vary in its impact among the region's economies, as it is mainly concentrated in very few industries that are less pro-poor or labor-intensive (especially, oil extraction, construction and utilities and services and tourism industries). In line with these studies, Bayar and Gunduz (2020) investigated the impact of FDI inflows on human capital development (expressed by the HDI of UNDP) in 11 EU transition economies in the period 1995-2018 using panel regression analysis. Their results showed that FDI inflows affect human capital development negatively and that the size of this effect is very weak (Bayar and Gunduz, 2020).

In addition, some other studies presented policies aiming to offset the negative effects of global economic fluctuations on human development. For example, the main purpose of Horváth et al. (2009) was to give a basis for policy decisions regarding human development after the global economic crisis. They tried to identify the optimal consistent mix of policies that is fiscally feasible and that also considers potential interactions among the different human development indicators and among the different used policy tools as well. Their study confirmed that social and labor market policies should be adjusted immediately after the crisis, taking into account that the effects of these policies take some time to occur (Horváth et al., 2009).

Horváth et al. (2009) also confirmed that the interventions of these policies should include not only social assistance to limit rising poverty but also a wide access to social services that is health and education, to avoid depreciation of human capital. In addition to social policy reforms, Horváth et al. (2009) indicated that temporary public employment programs can 
also mitigate the effect of job losses, and that these programs are efficient if they are considered a tool not an objective.

\section{An overview on human development in Egypt}

Egypt's human development had an increasing trend as HDI1 value increased by about $26.4 \%$ (from 0.55 to 0.69 ) in the period 1990-2015. In addition, HDI components increased in the same period: life expectancy at birth by 6.7 years, mean years of schooling by 3.6 years and expected years of schooling by 3.3 years. Also, Egypt's gross national income (GNI) per capita increased by $71.5 \%$ in the same period (UNDP, 2016). This upward trend in HDI and its indicators in Egypt is shown in Figure 1 and Table 1.

Although HDI is increasing over time, Egypt's ranking is still poor (111 out of 188 countries in 2015, medium human development category) (UNDP, 2016), as shown in the figure below.

Egypt's poor HDI ranking can be explained as follows: Egypt's expenditure on education and health has been low, with an average expenditure on health 5\% of GDP (1995-2014) and $12 \%$ on education (2003-2008) (World Bank). This was negatively reflected on labor performance and productivity, therefore decreasing total output, and hence, income levels (El Ghorab, 2016). In addition, the composition of public education expenditure in Egypt is

Figure 1.

HDI trend in Egypt (1990-2015)

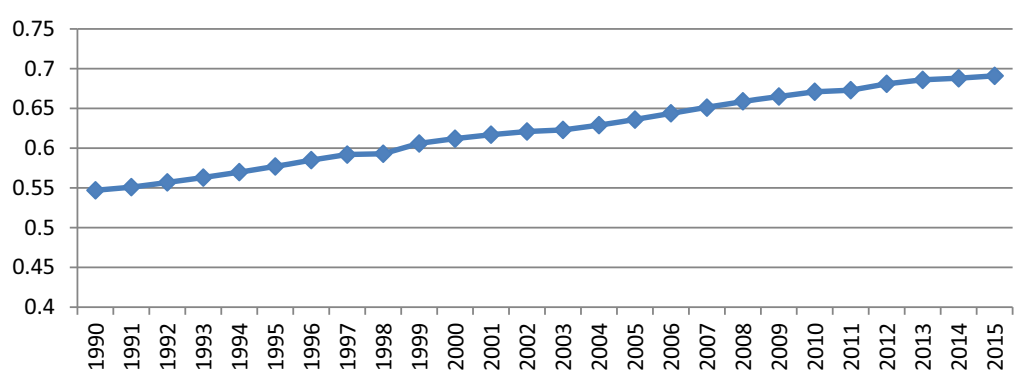

Source: Constructed by the authors based on UNDP (2016)

\begin{tabular}{lccccc}
\hline Years & $\begin{array}{c}\text { Life expectancy at } \\
\text { birth }\end{array}$ & $\begin{array}{c}\text { Expected years } \\
\text { of schooling }\end{array}$ & $\begin{array}{c}\text { Mean years of } \\
\text { schooling }\end{array}$ & $\begin{array}{c}\text { GNI per capita (2011 } \\
\text { PPP\$) }\end{array}$ & HDI value \\
\hline 1990 & 64.6 & 9.8 & 3.5 & 5,869 & 0.547 \\
1995 & 66.8 & 10.4 & 4.1 & 6,437 & 0.577 \\
2000 & 68.6 & 11.1 & 4.8 & 7,629 & 0.612 \\
2005 & 69.4 & 11.5 & 5.6 & 8,175 & 0.636 \\
2010 & 70.4 & 12.4 & 6.6 & 9,906 & 0.671 \\
2011 & 70.5 & 12.4 & 6.7 & 9,813 & 0.673 \\
2012 & 70.7 & 12.8 & 6.8 & 9,834 & 0.681 \\
2013 & 70.9 & 13.1 & 6.9 & 9,791 & 0.686 \\
2014 & 71.1 & 13.1 & 7.0 & 9,807 & 0.688 \\
2015 & 71.3 & 13.1 & 7.1 & 10,064 & 0.691 \\
\multicolumn{2}{l}{ Source: UNDP $(2016)$} & & & &
\end{tabular}


very biased toward expenditures on salaries and wages more than investment expenditures (El-Badaway and Hady, 2014).

In spite of increasing primary and preparatory education (compulsory) enrollment rate, as well as secondary and higher education [2], the students drop-out ratio in the primary level is quite high because of the higher costs of education after implementing the Economic Reform and Structural Adjustment Program, which made the poorest groups suffer more (El-Badaway and Hady, 2014). Regarding the quality of education, Egypt still suffers from the same problems of overcrowding, insufficient facilities, underpaid teachers and narrowminded teaching techniques (El Ghorab, 2016).

It is also important to refer to the "brain-drain," the international migration of high-level educated workers, that has been aggravated after the 2011 revolution, and which was related to the inconsistent policies in this period. A great number of brains left Egypt, worried about an uncertain future for themselves and their country (El-Badaway and Hady, 2014). There is also a bias in Egypt against technical and vocational careers, as technical and vocational training is considered like second-best education, which makes the situation even worse. It is widely known that training institutions in Egypt accept those students who have dropped out of the regular education system or have failed to pass their secondary level examinations and are not qualified to join the undergraduate university community (El-Sholkamy, 2016).

Moreover, after the Egyptian revolution in 2011, it was very difficult to have efficient policy integration and coordination between the different ministries (such as the Ministry of Education, the Ministry of Higher Education, the Ministry of Industry and the Ministry of Manpower) given the multiple government changes over a short period (El-Badaway and Hady, 2014). Thus, the lack of coordination among ministries and institutions made the human resources development more challenging, as this coordination would have helped identify shortages, avoid replication, duplication and excess supply, learn from successful experiences and allocate resources for human resources development. Besides this coordination, Egypt needs essential accurate information and databases to support policymaking, as mentioned in the International Labour Organization (ILO) Egypt Report for February 2014 (El-Sholkamy, 2016).

In addition to the above mentioned obstacles, global financial crises and economic slowdown had an adverse impact on the Egyptian economy and its growth path. As foreign demand decreased, exports of goods and services deteriorated, hence lowering economic growth and rising unemployment rate. The balance of payments turned into a deficit because of the diminishing current account receipts from exports of goods and services and from remittances, besides the decrease in foreign investment flows (Ramadan and Hegazy, 2009). Consequently, the shortfall in the financial capability may justify the decline of Egypt's ability to advance its programs of human development, as reflected in its poor HDI ranking.

\section{The methodology}

The paper is trying to estimate the impact of international economic fluctuations on HDI in Egypt, considering the transmission channels, in the period 1990-2015 (1990 the first year for HDI data). A VAR model is used to examine the above mentioned relationship. A unit root test will be conducted before estimating the VAR model because stationary time series is a precondition for the validity of the VAR model (Boheman and Maxén, 2015). The VAR analysis implies examining the impulse response functions and variance decompositions. 


\subsection{Variables and data sources}

- (HDI): HDI is used as a measure of human development. According to UNDP (2016), HDI is defined as "a measure for assessing progress in three basic dimensions of human development: a long and healthy life, access to knowledge and a decent standard of living. A long and healthy life is measured by life expectancy at birth. Knowledge level is measured by mean years of education among the adult population, which is the average number of years of education received in a life-time by people aged 25 years and older; and access to learning and knowledge by expected years of schooling for children of school-entry age, which is the total number of years of schooling a child of school-entry age can expect to receive if prevailing patterns of age-specific enrollment rates stay the same throughout the child's life. The standard of living is measured by GNI per capita expressed in constant 2011 international dollars converted using purchasing power parity conversion rates."

- (Globfluct): Global Economic Fluctuations are calculated as the volatility in the world annual growth rate of GDP using the ARCH-GARCH [3] model as in many previous studies (Fang and Miller, 2009).

- (FDI): FDI net inflows \% of GDP [4].

- (ODA): Net ODA received \% of GNI. It includes grants, financial flows and technical cooperation.

- (Expor): Exports of goods and services \% of GDP.

- (Remita): Personal remittances received \% of GDP, they comprise personal transfers and compensation of employees.

All data are obtained from the World Bank, World Development Indicators [5], except for HDI whose data are from the UNDP, Human Development Report [6].

\subsection{Vector autoregressive model [7]}

The study uses the VAR model, as a large majority of studies used it to investigate the impact of the financial crisis shock and its transmission channels on emerging and developing economies (Alymkulova and Ganiev, 2020; Alam, 2012). Also, VAR is considered a reliable way in detecting and capturing interactions among the variables (Can et al., 2020). In the VAR model, the changes of any variable depend on the changes of its own lags and the changes of other variables' lags. Then, the variables in the VAR model are all considered as endogenous (Baškot, 2020; Boheman and Maxén, 2015; Alymkulova and Ganiev, 2020). The model can be generally represented by the following equation:

$$
\mathrm{y}_{\mathrm{t}}=\mathrm{a}_{0}+\mathrm{a}_{1} \mathrm{y}_{\mathrm{t}-1}+\ldots \ldots \ldots+\mathrm{apy}_{\mathrm{t}-\mathrm{P}}+\boldsymbol{\varepsilon}_{\mathrm{t}}
$$

where: $\mathrm{y}_{\mathrm{t}}$ is the vector of endogenous variables; $\mathrm{a}_{\mathrm{p}}$ is the matrix of autoregression parameters from $1, \ldots, \mathrm{P} ; \mathrm{a}_{0}$ is the vector of constant term; $\varepsilon_{\mathrm{t}}$ is the vector of error terms (Ulrichs, 2018).

A VAR model consists of a number of equations equal to the number of variables included in the model. So, a VAR with $\mathrm{K}$ time series variables consists of K equations, one for each of the variables, where the regressors in all equations are lagged values of all the variables. The coefficients of the VAR are estimated by estimating each of the equations by ordinary least squares (Stock and Watson, 2015). Therefore, in our model there are six equations for every variable at time $(\mathrm{t})$ and where $(\mathrm{j})$ is the time lag and $\mathrm{e}_{1 \mathrm{t}} \ldots \ldots \ldots \mathrm{e}_{6 \mathrm{t}}$ are error terms [8], as follows: 


$$
\begin{aligned}
\text { Globfluct }_{t}= & \beta_{10}+\sum_{j=1}^{p} \beta_{11 j} \text { Globfluct }_{t-j}+\sum_{j=1}^{p} \beta_{12 j} \text { FDI }_{t-j}+\sum_{j=1}^{p} \beta_{13 j} O D A_{t-j} \\
& +\sum_{j=1}^{p} \beta_{14 j} \text { Expor }_{t-j}+\sum_{j=1}^{p} \beta_{15 j} \text { Remit }_{t-j} \\
& +\sum_{j=1}^{p} \beta_{16 j} \text { HDI }_{t-j}+e_{1 t}
\end{aligned}
$$

$$
\begin{aligned}
F D I_{t}= & \beta_{20}+\sum_{j=1}^{p} \beta_{21 j} \text { Globfluct }_{t-j}+\sum_{j=1}^{p} \beta_{22 j} F D I_{t-j}+\sum_{j=1}^{p} \beta_{23 j} O D A_{t-j} \\
& +\sum_{j=1}^{p} \beta_{24 j} \text { Expor }_{t-j}+\sum_{j=1}^{p} \beta_{25 j} \text { Remita }_{t-j} \\
& +\sum_{j=1}^{p} \beta_{26 j} \text { HDI }_{t-j}+e_{2 t}
\end{aligned}
$$

$$
\begin{aligned}
\text { ODA }_{t}= & \beta_{30}+\sum_{j=1}^{p} \beta_{31 j} \text { Globfluct }_{t-j}+\sum_{j=1}^{p} \beta_{32 j} F D I_{t-j}+\sum_{j=1}^{p} \beta_{33 j} O D A_{t-j} \\
& +\sum_{j=1}^{p} \beta_{34 j} \text { Expor }_{t-j}+\sum_{j=1}^{p} \beta_{35 j} \text { Remita }_{t-j} \\
& +\sum_{j=1}^{p} \beta_{36 j} \text { HDI }_{t-j}+e_{3 t}
\end{aligned}
$$

$$
\begin{aligned}
\text { Expor }_{t}= & \beta_{40}+\sum_{j=1}^{p} \beta_{41 j} \text { Globfluct }_{t-j}+\sum_{j=1}^{p} \beta_{42 j} F D I_{t-j}+\sum_{j=1}^{p} \beta_{43 j} O D A_{t-j} \\
& +\sum_{j=1}^{p} \beta_{44 j} \text { Expor }_{t-j}+\sum_{j=1}^{p} \beta_{45 j} \text { Remita }_{t-j} \\
& +\sum_{j=1}^{p} \beta_{46 j} H D I_{t-j}+e_{4 t}
\end{aligned}
$$

$$
\begin{aligned}
\text { Remita }_{t}= & \beta_{50}+\sum_{j=1}^{p} \beta_{51 j} \text { Globfluct }_{t-j}+\sum_{j=1}^{p} \beta_{52 j} \text { FDI }_{t-j}+\sum_{j=1}^{p} \beta_{53 j} O D A_{t-j} \\
& +\sum_{j=1}^{p} \beta_{54 j} \text { Expor }_{t-j}+\sum_{j=1}^{p} \beta_{55 j} \text { Remita }_{t-j} \\
& +\sum_{j=1}^{p} \beta_{56 j} H D I_{t-j}+e_{5 t}
\end{aligned}
$$


REPS

$$
\begin{aligned}
H D I_{t}= & \beta_{60}+\sum_{j=1}^{p} \beta_{61 j} \text { Globfluct }_{t-j}+\sum_{j=1}^{p} \beta_{62 j} F D I_{t-j}+\sum_{j=1}^{p} \beta_{63 j} O D A_{t-j} \\
& +\sum_{j=1}^{p} \beta_{64 j} \text { Expor }_{t-j}+\sum_{j=1}^{p} \beta_{65 j} \text { Remita }_{t-j} \\
& +\sum_{j=1}^{p} \beta_{66 j} H{ } I_{t-j}+e_{6 t}
\end{aligned}
$$

\section{Empirical results and discussion}

\subsection{Unit root test}

To check if the data contain unit root, we applied the Kwiatkowski-Phillips-Schmidt-Shin test where the null hypothesis is that there is no unit root in the data. The test concluded that all of the variables were stationary as shown in Table 2, where the calculated lagrange multiplier statistics are less than the critical value, therefore we cannot reject the null hypothesis.

\subsection{Choosing lag length}

In a VAR model, it is important to determine the optimal lag length. There are some criteria used (Pratikto, 2012) as shown in Table 3.

\begin{tabular}{|c|c|c|c|}
\hline \multirow[b]{2}{*}{ Variable } & & \multicolumn{2}{|c|}{ KPSS test statistic (LM stat.) } \\
\hline & & Constant & Constant and linear trend \\
\hline HDI & & $0.754146^{*}$ & 0.113043 \\
\hline GLOBFLUCT & & 0.153219 & 0.086860 \\
\hline FDI & & 0.165757 & 0.084335 \\
\hline ODA & & 0.549866 & 0.174163 \\
\hline EXPOR & & 0.138536 & 0.104214 \\
\hline REMITA & & 0.265520 & 0.160156 \\
\hline Critical values & $1 \%$ & 0.739000 & 0.216000 \\
\hline & $5 \%$ & 0.463000 & 0.146000 \\
\hline & $10 \%$ & 0.347000 & 0.119000 \\
\hline
\end{tabular}

According to the final prediction error, the Akaike information criterion and the HannanQuinn information criterion, the lag length suggested is two, while the likelihood ratio test

Table 2.

KPSS test results

Note: *Not stationary using constant

Source: Authors' calculations using Eviews 9

Table 3.

\begin{tabular}{lcccccc}
\hline Lag & LogL & LR & FPE & AIC & SC & HQ \\
\hline 0 & -219.7291 & NA & 5.952372 & 18.81076 & 19.10528 & 18.88890 \\
1 & -68.29993 & $214.5247^{*}$ & 0.000439 & 9.191661 & $11.25326 *$ & 9.738603 \\
2 & -22.12048 & 42.33116 & $0.000369^{*}$ & $8.343374^{*}$ & 12.17205 & $9.359122^{*}$
\end{tabular}

Selection of optimum Note: "Means the lag length suggested by this criterion lag length

Source: Authors' calculations using Eviews 9 
and Schwarz Information Criterion only suggested one lag, then our VAR model will be with two lags.

\subsection{Model stability}

To check whether this VAR model is stable or not, the stability test was conducted and showed, through AR ROOTS table and AR ROOTS Graph, that VAR satisfies the stability condition because "no root lies outside the unit circle," as shown in Figure 3.

\subsection{Impulse response functions}

Impulse responses detect the responsiveness of the dependent variables in the VAR model to shocks to each of the variables. So, for each variable from each equation separately, a unit shock is applied to the error and the effects are observed upon the VAR system over time. The shock should fade away gradually, provided that the system is stable (Brooks, 2008).

More precisely, the impulse response functions (IRFs) show how one standard deviation shock in one variable's residuals affects the other variables, and for how long the shock has

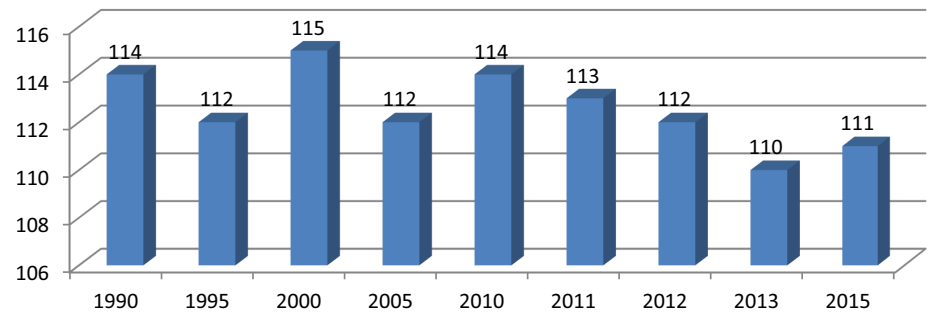

Source: Constructed by the authors based on UNDP (several issues)

Figure 2. Egypt's HDI Ranking (1990-2015)

\section{Inverse Roots of AR Characteristic Polynomial}

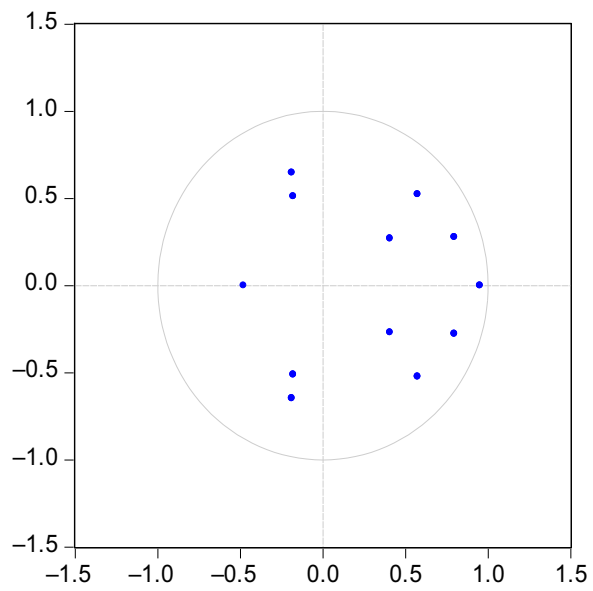

Figure 3. 


\section{REPS}

an effect on the variables (Boheman and Maxén, 2015). Then, the impulse response functions here illustrate how one standard deviation shock in international economic fluctuations, FDI, exports, remittances, ODA and HDI affects HDI within 10 periods. The impulse response functions within 10 periods are represented in Figure 4.

A shock to global fluctuations has a negative effect on HDI throughout the period as expected, after three years this negative effect began to decrease over time but without reaching zero. Global economic fluctuations may have this negative effect because in crisis time, government revenues from foreign resources (FDI, exports, tourism and foreign aid) decrease. This supports the findings of Panizza (2001) and El Husseiny (2018), which showed that international financing often decreases during economic downturns.

IRF's illustrate also that there is a positive relationship between FDI and HDI, but the effect of the shock to FDI disappears by the eighth year. This result is in line with Sharma and Gani (2004), which suggests that increases in FDI are associated with slight improvements in human development, given that it is now known that FDI has positive effects on the economic growth and export earnings of host countries. Other possible benefits from FDI include technology transfer, increased production efficiency and quality improvement. These attributes positively influence the components of HDI (Sharma and Gani, 2004). Consequently, when FDI deteriorates in recessions, HDI decreases too and this effect remains till the eighth year. So, after global fluctuations, the flow of FDI declines as the crisis undermines FDI flows, makes investors more cautious and increases their need for

Response to Cholesky One S.D. Innovations
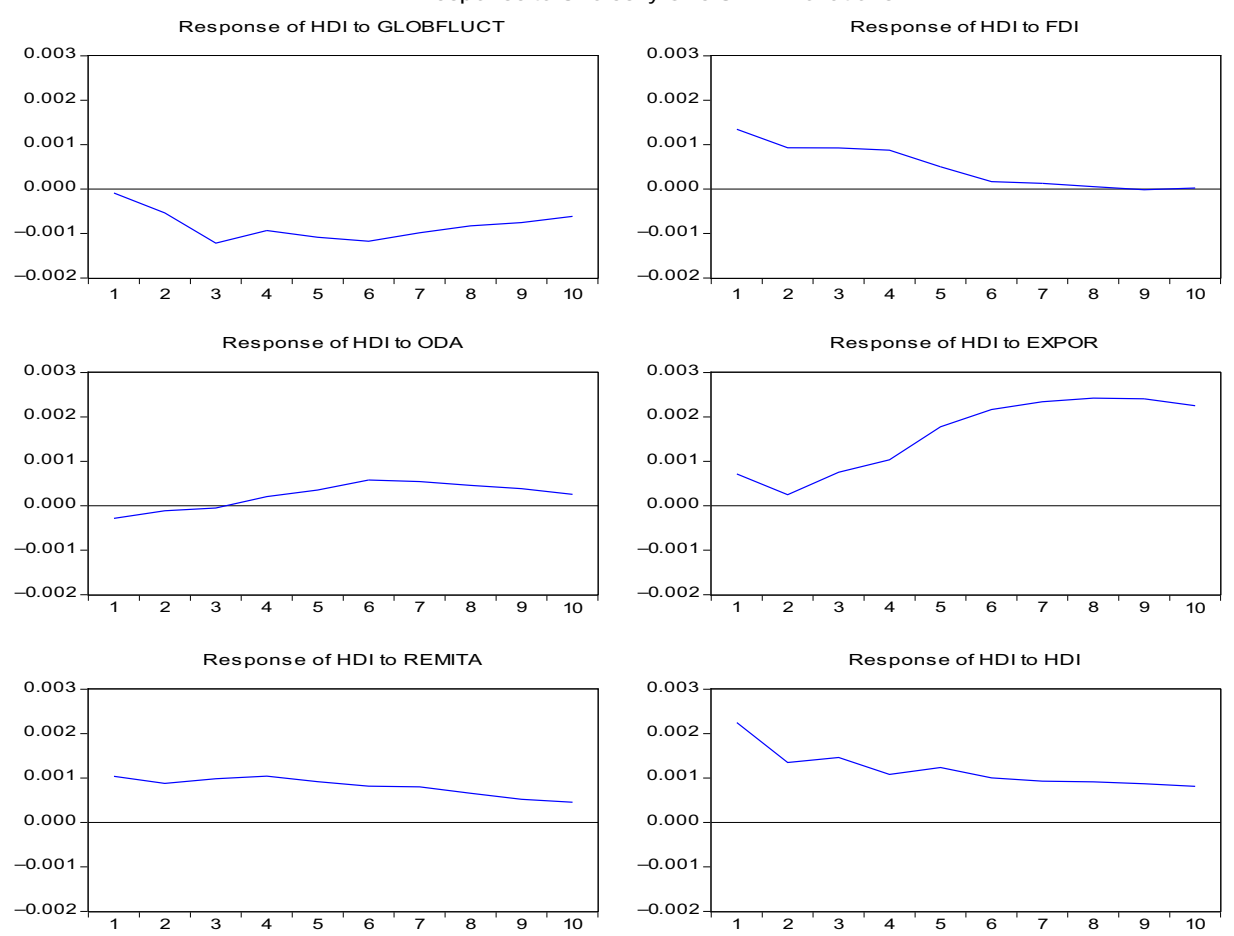

Figure 4.
Impulse response functions for HDI

Source: Eviews 9 
liquidity. For example, in 2007/2008, what made the situation more serious is that two-thirds of foreign investments in Egypt came from the US and European countries, while a number of them was either already in or were entering into recession (Abu Hatab, 2009). This is reflected on the gradually diminishing impact of FDI on economic and human development.

IRF's show also that a shock in ODA will have a negative relationship with HDI in the first three years, then it will turn into a positive relationship until the end of the period, which means that when ODA decreases after any global shock, HDI will also decrease (positive relationship), not immediately but after a while (here in the case of Egypt after three years).

Although ODA is considered an important source of finance for the majority of developing countries and complements domestic savings and government expenditures, studies have found that it is not a guarantee that an increase in aid leads to increased human capital development (El-Sholkamy, 2016).

There is a positive relationship between export shocks and HDI throughout the period, and this positive relation increases over time. After any international shock, foreign demand decreases, then export revenues diminish, which is reflected negatively on government revenues and affects its expenditure, including spending on education and health. This negative effect of decreasing export revenues persists throughout the period.

As for the remittances, IRF's illustrate a positive relationship between remittance shocks and HDI throughout the period but this relationship grows weaker through time. Therefore, any negative shock to remittances leads to a decrease in HDI. This result agrees with Adenutsi (2010), who concluded that remittances have a positive impact on human development in the long run, and Ustubici and Irdam (2012), who agreed that there is a positive correlation between remittances and human development, as well as Shirazi et al. (2018), who found that the increased flows of remittances improve the level of consumption and build human capital.

Over the periods 2001/2002-2014/2015, Egypt witnessed positive remittances growth rates, except for 2008/2009 when remittances dropped by almost $9 \%$, influenced by the global financial crisis. The US has been the main remittances source for Egypt from 2002 until late 2009. After the financial crisis, workers' remittances from the US dropped from $\$ 2.3 \mathrm{bn}$ in 2009 to 534 million in 2010. Nevertheless, the negative growth rates did not last for a longer period (Helmy et al., 2016). Then, the two main destinations, US (the largest proportion of remittances of emigrant workers) and the Gulf countries (the largest

\begin{tabular}{lccccccc}
\hline Period & S.E. & GLOBFLUCT & FDI & ODA & EXPOR & REMITA & HDI \\
\hline 1 & 3.440009 & 0.092871 & 21.16700 & 0.944471 & 5.999759 & 12.64656 & 59.14934 \\
2 & 4.334721 & 2.406557 & 21.61910 & 0.753045 & 4.654929 & 14.98430 & 55.58207 \\
3 & 4.510520 & 9.685683 & 19.19585 & 0.519732 & 6.241201 & 15.33908 & 49.01846 \\
4 & 4.688496 & 11.34255 & 18.35995 & 0.592683 & 9.477231 & 16.70921 & 43.51837 \\
5 & 4.992312 & 12.56744 & 14.91282 & 0.867193 & 17.65042 & 15.59135 & 38.41078 \\
6 & 5.287487 & 13.49956 & 11.85246 & 1.553109 & 26.09127 & 14.04922 & 32.95438 \\
7 & 5.358943 & 13.18427 & 9.795521 & 1.909073 & 33.18815 & 12.93985 & 28.98314 \\
8 & 5.407525 & 12.50044 & 8.364824 & 2.015097 & 39.02402 & 11.83402 & 26.26161 \\
9 & 5.426635 & 11.89716 & 7.355443 & 2.008441 & 43.58718 & 10.84376 & 24.30801 \\
10 & 5.461490 & 11.34017 & 6.673878 & 1.917574 & 46.91675 & 10.13955 & 23.01208
\end{tabular}

Source: Calculated by Eviews 9

Table 4.

Variance decomposition results 
percentage of workers), were struggling to get rid of the negative impacts of the financial crisis (Abu Hatab, 2009).

Finally, HDI decreases in response to its own negative shock. As IRF's show, there is a positive relationship between HDI and itself over time as expected, as human capital development is an accumulative process, so the first negative effect will cause a deterioration in human capital accumulation that will be slightly fixed by the seventh year.

\subsection{Variance decompositions}

Besides IRFs, there is another method used to examine VAR system dynamics, which is variance decompositions, and it somewhat gives very similar information as impulse responses. Variance decompositions give the proportion of the changes in the dependent variables due to their own shocks and shocks to the other variables. A shock to any variable will influence this variable, and will also affect all variables in the VAR system. It is generally detected in practice that most of the error variance of the variable, in a VAR, is explained by its own shocks (Brooks, 2008). This is shown in Table 5.

The table illustrates the importance of a shock in one variable to itself and to the other variables in 10 periods. If we look to the importance of different shocks in the short-run (in

\section{Figure 5.}

Variance decompositions results in the short run

\section{Figure 6.}

Variance decompositions results in the long run

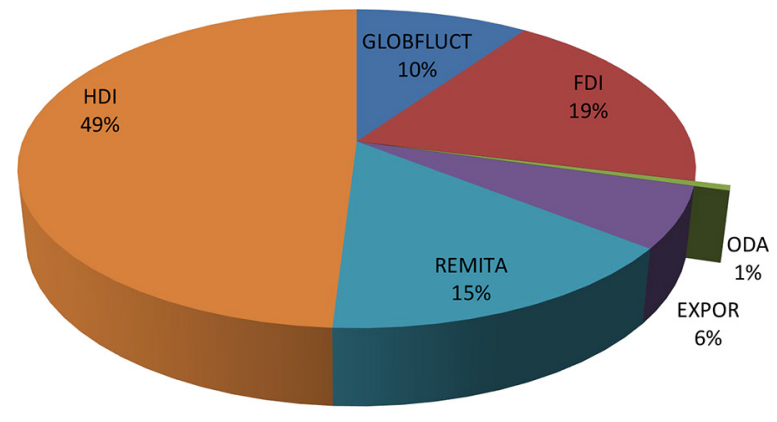

Source: Constructed by the authors based on Eviews 9 calculations

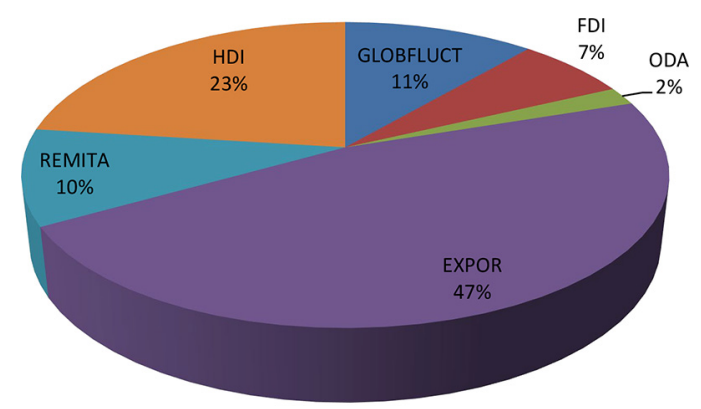

Source: Constructed by the authors based on Eviews 9 calculations 
three years), error variance decompositions results show that $50 \%$ of variance in HDI is explained by its own shock. The most influencing shock after HDI itself is FDI, then remittances, exports, global fluctuations and finally ODA (only by $1 \%$ ).

It is obvious from variance decompositions results that, in the long run, the importance of HDI shock declined to explain only $23 \%$ of its variation, while the effect of other shocks increased. The most important source in explaining the HDI variation became shocks to exports $(47 \%$, which is consistent with IRFs results that positive relationship between exports and HDI is increasing over time), followed by global economic fluctuations then remittances, FDI and the least important shock, like in the short run, was ODA ( $2 \%$ ).

\section{Conclusion and policy implications}

There is no simple way to illustrate the effects of economic fluctuations on human development. However, previous literature on economic crises suggests that they cause serious risks to human development outcomes (Conceição et al., 2010), but this literature has not specifically addressed the effect of global economic fluctuations on human development in Egypt as an open developing economy and their transmission channels. Therefore, this paper aimed at investigating the relationship between economic fluctuations and human development and at determining the most important transmission channels of these fluctuations to guide policymakers in promoting human development.

Depending on a VAR model that implies the impulse response functions and variance decompositions, the relationships have been examined for a data set that covers the period 1990-2015. The empirical results have shown the following:

- Impulse response functions and variance decompositions showed that a shock to global fluctuations has a negative effect on HDI throughout the period as expected; after three years this negative effect began to decrease over time. Global economic fluctuations may have this negative effect because in crisis time, government revenues from foreign resources (FDI, exports, tourism and foreign aid) decrease. This supports the findings of Panizza (2001) and El Husseiny (2018), which mentioned that international financing often decreases during economic downturns. In addition, the paper showed that there is a positive relationship between FDI and HDI, which is in line with Sharma and Gani (2004). Consequently, after global fluctuations, the flow of FDI declines, which leads to a decrease in HDI, and this effect remains till the eighth year.

- A shock in ODA has a negative relationship with HDI in the first three years, then it turns into a positive relationship until the end of the period. This may explain that even if ODA decreases after any global shock, HDI will not decrease immediately but after three years, which is in line with El-Sholkamy (2016).

- There is a positive relationship between export shocks and HDI throughout the period, and this positive relation also increases through time. These results are consistent with Levin and Raut (1997).

- As for remittances, there is a positive relationship between remittance shocks and HDI throughout the period, but it weakens through time. Therefore, any negative shock to remittances leads to a decrease in HDI. This agrees with the findings of Adenutsi (2010) and Ustubici and Irdam (2012).

- In the short run (in three years), error variance decompositions results showed that the most influencing shock is FDI then remittances, exports, global fluctuations and finally ODA (only by $1 \%$ ). 
In the long run, variance decompositions showed that the most important channel in explaining the HDI variation became shocks to exports (47\%), followed by global economic fluctuations then remittances, FDI and ODA ( $2 \%)$, which was the least important shock. The above results show that policies should consider the effects both in the short run and the long run. In the period of crises, policymakers should deal with the large impact of FDI and remittances on HDI in the short run by motivating foreign investments to remain in Egypt and encouraging the long run contracts with foreign investors to avoid the decline in human development when FDI decreases. Besides that, they may try to transform foreign aid into FDI inflows that will stimulate importing technical know-how and capital, and create job opportunities (EL-Sholkamy, 2016). In addition, they should encourage Egyptians abroad to increase remittance flows to help their families maintain the consumption level of goods and services, including those contributing to human development. Moreover, taking into account the high export revenues impact in the long run, policies that increase and diversify exports should be introduced, especially by depending on high value added goods and services more than primary goods. At the same time, the export support fund should play a vital role in sustaining export revenues by entering into long-run contracts with foreign importers and promoting the high value added exports such as high technology and creative exports.

In addition, and to achieve progress in HDI ranking and limit human development erosion during and after economic crises, social policies in the areas of nutrition, health and basic education should be the main center of attention in policymaking. These policies should be complemented with targeted programs for the poor, such as conditional cash transfers (such as Takaful and Karama program in Egypt) and temporary employment programs (Griffith-Jones and Ocampo, 2009). However, while temporary employment programs presented by governments provide income security for those included and enhance their living situation temporarily, experience indicates that governments should leave the role of employment provider to the private sector (Horváth et al., 2009).

Moreover, enhancing the quality of services in health and education should continue after any crisis, as health and education sectors often suffer from expenditure reduction plans because of the drop in public revenues, ODA and other financial resources (FDI, exports, etc.) after an economic crisis tightens the fiscal space necessary to preserve expenditure on education, health and social protection (Conceição et al., 2010). Therefore, comprehensive increases in budgetary spending should be excluded and instead careful targeting is needed to guarantee effective alleviation of human development loss (Horváth et al., 2009).

\section{Notes}

1. HDI of less than 0.550 refers to low human development, 0.550-0.699 to medium human development, $0.700-0.799$ to high human development and 0.800 or greater to very high human development.

2. Gross Primary School Enrollment (\%) $=103 \%$ in 2016, Gross Secondary School Enrollment (\%) $=85.9 \%$ in 2016, Gross Tertiary School Enrollment $(\%)=34.4 \%$ in 2016, Children out of school ( $\%$ of primary school age) $=1.4 \%$ in 2016 (World bank, World Development Indicators).

3. Generalized/Autoregressive Conditional Heteroskedasticity.

4. This series shows net inflows (new investment inflows less disinvestment) in the reporting economy from foreign investors and is divided by GDP.

5. https://data.worldbank.org/indicator?tab=all.

6. http://hdr.undp.org/en/indicators/137506\#. 
7. For further information: (Brooks, 2008; Luetkepohl, 2011).

8. For further information: (Pratikto, 2012).

\section{Global economic fluctuations}

\section{References}

Abu Hatab, A.R. (2009), "Egypt within the framework of the global financial crisis: impact, response and way forward”, International Journal of Middle Eastern Studies, Vol. 2 No. 1, pp. 7-25.

Adenutsi, D.E. (2010), "Do international remittances promote human development in poor countries? Empirical evidence from Sub-Saharan Africa”, The International Journal of Applied Economics and Finance, Vol. 4 No. 1, pp. 31-45.

Alam, A. (2012), "Crisis transmission: global financial crisis", Journal of Risk Analysis and Crisis Response, Vol. 2 No. 3, pp. 157-165.

Alymkulova, N. and Ganiev, J. (2020), "Global financial economic crisis transmission on the transition economy: Case of the Kyrgyz republic", Journal of Financial Economic Policy, Vol. 12 No. 1, pp. 1-22, available at: https://doi.org/10.1108/JFEP-09-2018-0133

Baškot, B. (2020), "Capital flows impact on labor market: how do FDIs and remittances effect youth employment in Bosnia And Herzegovina?”, Economic Research-Ekonomska Istraživanja, Vol. 33 No. 1, pp. 2633-2647.

Bayar, Y. and Gunduz, M. (2020), "The impact of foreign direct investment inflows and trade liberalization on human capital development in EU transition economies", Online Journal Modelling The New Europe, No. 32/2020.

(2015), Bedir, S. "The Asymmetric impact of growth fluctuation on human development", Eurasian Journal of Social Sciences, Vol. 3 No. 2, pp. 24-34.

Black, S.E. and Sokoloff, K.L. (2006), "Long-term trends in schooling: the rise and decline (?) of public education in the United States", Handbook of the Economics of Education, Vol. 1, pp. 69-105.

Boheman, H. and Maxén, J. (2015), "Oil price shocks effect on economic growth: OPEC versus non-OPEC economies", Unpublished Thesis, School of Economics and Management, Lund University.

Brooks, C. (2008), Introductory Econometrics for Finance, 2nd ed., Cambridge University Press, Cambridge.

Can, U., Bocuoglu, M.E. and Can, Z.G. (2020), "How does the monetary transmission mechanism work? Evidence from Turkey”, Borsa_Istanbul Review, doi: 10.1016/j.bir.2020.05.004.

Conceição, P. and Kim, N. (2009), "The asymmetric impact of growth fluctuation on human development: evidence from correlates of growth decelerations and accelerations", A UNDP/ODS Working Paper, May 2009, United Nations Development Programme, Office of Development Studies.

Conceição, P., Mukherjee, S. and Nayyar, S. (2010), "Impacts of the economic crisis on human development and the MDGs in Africa", Discussion Paper, April 2010, United Nations Development Programme, Bureau for Development Policy, Poverty Group.

Dang, H.A., Knack, S. and Rogers, F.H. (2013), "International aid and financial crises in donor countries", European Journal of Political Economy, Vol. 32, pp. 232-250.

De Beer, P. (2012), "Earnings and income inequality in the EU during the crisis", International Labour Review, Vol. 151 No. 4, pp. 313-331.

De, S., Islamaj, E., Kose, M. and Yousefi, S.R. (2016), "Remittances over the business cycle: theory and evidence", Koç University-TÜSIAD Economic Research Forum Working Paper Series, No. 1601.

De Sousa, G.L. (2010), "The financial crisis impact on human development", paper presented at the 7th Pan-European International Relations Conference organized by the Standing Group on International Relations (SGIR), 9-11 September, Stockholm. 


\section{REPS}

Duryea, S., Lam, D. and Levison, D. (2007), "Effects of economic shocks on children's employment and schooling in Brazil", Journal of Development Economics, Vol. 84 No. 1, pp. 188-214.

El-Badaway, T.A. and Hady, N. (2014), "An overview of human resource development in pre and post revolution Egypt and its efforts towards reaching sustainable development", Journal of Human Resources Management and Labor, pp. 39-77.

El Husseiny, I.A. (2018), "On the cyclical behavior of fiscal policy in Egypt", Contemporary Economics, Vol. 12 No. 1, pp. 95-124.

El Ghorab, N.M. (2016), "Egypt and Malaysia: investment, education and economic growth", The Undergraduate Research Journal, Vol. 4, pp. 128-144.

EL-Sholkamy, M.M. (2016), "Human capital development in Egypt: foreign aid efforts towards sustainable development", International Journal of Management and Applied Science, Vol. 2 No. 9, Special Issue-1, September.

Fang, W. and Miller, S.M. (2009), "Modeling the volatility of real GDP growth: the case of Japan revisited", Japan and the World Economy, Vol. 21 No. 3, pp. 312-324.

Ferreira, F.H. and Schady, N. (2009), Social Consequences of the Global Financial Crisis in Latin America: Some Preliminary, and Surprisingly Optimistic, Conjectures, The World Bank, No. 53546.

Fielding, D. and Mavrotas, G. (2008), "Aid volatility and donor-recipient characteristics in 'difficult partnership countries", Economica, Vol. 75 No. 299, pp. 481-494.

Friedman, J. and Schady, N. (2009), How Many More Infants are Likely to Die in Africa as a Result of the Global Financial Crisis?, The World Bank.

Griffith-Jones, S. and Ocampo, J.A. (2009), "The financial crisis and its impact on developing countries", Poverty Reduction Discussion Paper No. PG/2009/001, January, UNDP.

Goldin, C. (2001), "The human-capital century and American leadership: virtues of the past", The Journal of Economic History, Vol. 61 No. 2, pp. 263-292.

Goldin, I., Rogers, H. and Stern, N. (2002), "The role and effectiveness of development assistance: lessons from World Bank experience", A Research Paper from the Development Economics Vice Presidency of the World Bank, The World Bank, Washington, DC.

Habib, B., Narayan, A., Olivieri, S. and Sanchez-Paramo, C. (2010), "The impact of the financial crisis on poverty and income distribution: insights from simulations in selected countries", Economic Premise, Vol. 7, pp. 1-4.

Horváth, B., Ivanov, A., Peleah, M. and Pospíšilová, M. (2009), “The human development impact of the global crisis in Central, Eastern and Southern Europe, and the CIS", available at: www.ilo.org/ wcmsp5/groups/public/--europe/-ro-geneva/documents/meetingdocument/wcms_367057.pdf

Helmy, O., Zaki, C. and Abdallah, A. (2016), "Do workers' remittances promote consumption stability in Egypt?”, The Egyptian Center for Economic Studies Working Paper No. 187.

IMF (2015), World Economic Outlook, International Monetary Fund.

Irdam, D. (2012), "The impact of remittances on human development: a quantitative analysis and policy implications", Sociology, Vol. 5 No. 1, pp. 74-95.

Jacoby, H.G. and Skoufias, E. (1997), "Risk, financial markets, and human capital in a developing country", The Review of Economic Studies, Vol. 64 No. 3, pp. 311-335.

Kazi, M. (2014), "Investigating the transmission channels of the global financial crisis to Tanzania", Modern Economy, Vol. 5 No. 4, pp. 324-332.

Kumi, E., Ibrahim, M. and Yeboah, T. (2017), "Aid volatility and structural economic transformation in Sub-Saharan Africa: does finance matter?”, Economic Research Southern Africa (ERSA) Working paper No. 655.

Lehnert, K., Benmamoun, M. and Zhao, H. (2013), "FDI inflow and human development: analysis of FDI's impact on host countries social welfare and infrastructure", Thunderbird International Business Review, Vol. 55 No. 3, pp. 285-298. 
Levin, A. and Raut, L.K. (1997), "Complementarities between exports and human capital in economic growth: evidence from the semi-industrialized countries", Economic Development and Cultural Change, Vol. 46 No. 1, pp. 155-174.

Luetkepohl, H. (2011), Vector Autoregressive Models, EUI working paper ECO2011/30, Department of economics, European University Institute.

McKenzie, D.J. (2003), "How do households cope with aggregate shocks? Evidence from the Mexican peso crisis", World Development, Vol. 31 No. 7, pp. 1179-1199.

Miller, C. (2010), "The human development impact of economic crisis", Human Development Report 2005, UNDP.

Oryoie, A.R. and Alwang, J. (2018), "School attendance and economic shocks: evidence from rural Zimbabwe", Development Southern Africa, Vol. 35 No. 6, pp. 803-814.

Pallage, S. and Robe, M.A. (2001), "Foreign aid and the business cycle", Review of International Economics, Vol. 9 No. 4, pp. 641-672.

Pallage, S. and Robe, M.A. (2003), "On the welfare cost of economic fluctuations in developing countries", International Economic Review, Vol. 44 No. 2, pp. 677-698.

Panizza, U. (2001), "Macroeconomic policies in Egypt: an interpretation of the past and options for the future", The Egyptian Center for Economic Studies Working Paper No. 61.

Paxson, C. and Schady, N. (2005), "Child health and economic crisis in Peru", The World Bank Economic Review, Vol. 19 No. 2, pp. 203-223.

Pérez-Segura, A. (2014), "FDI and human development: what is the role of governance?", Doctoral dissertation, Honors Thesis.

Ponce, J., Olivié Aldasoro, L. and Onofa, M. (2008), "Remittances for development? A case study of the impact of remittances on human development in Ecuador", Elcano Newsletter, Vol. 48 No. 33.

Pratikto, R. (2012), "Dynamics of Indonesia's international trade a VAR approach", Procedia Economics and Finance, Vol. 4, pp. 149-159.

Ramadan, O. and Hegazy, A. (2009), Egypt Response to the Global Crises, Ministry of Finance, Macro Fiscal Policy Unit Cairo.

Reiter, S.L. and Steensma, H.K. (2010), "Human development and foreign direct investment in developing countries: the influence of FDI policy and corruption", World Development, Vol. 38 No. 12, pp. 1678-1691.

Schmitt-Grohé, S. (1998), "The international transmission of economic fluctuations: effects of US business cycles on the Canadian economy", Journal of International Economics, Vol. 44 No. 2, pp. 257-287.

Sharma, B. and Gani, A. (2004), "The effects of foreign direct investment on human development", Global Economy Journal, Vol. 4 No. 2.

Shirazi, N.S., Javed, S.A. and Ashraf, D. (2018), “ "Remittances, economic growth and poverty: a case of African OIC member countries", The Pakistan Development Review, Vol. 57 No. 2, pp. 121-143.

Soumaré, I. (2015), “Does foreign direct investment improve welfare in North African countries?”, AFDB, North Africa Policy series, available at: www.afdb.org

Stock, J.H. and Watson, M.W. (2015), Introduction to Econometrics, Update, 3rd ed., Pearson.

Ulrichs, M. (2018), "Identification of financial and macroeconomic shocks in a VAR model of the polish economy: a stability analysis", Economics and Business Review, Vol. 4 No. 1, pp. 29-43.UNDP (Several issues), Human Development Report, available at: http://hdr.undp. org/en/global-reports

UNDP (2016), "Human development for everyone: briefing note for countries on the 2016", Human Development Report (Egypt), available at: http:/hdr.undp.org/sites/all/themes/hdr_theme/ country-notes/EGY.pdf 
Ustubici, A. and Irdam, D. (2012), "The impact of remittances on human development: a quantitative analysis and policy implications", Economics and Sociology, Vol. 5 No. 1, pp. 74-95.

World Bank (2021), "World development indicators", available at: https://data.worldbank.org/ indicator?tab=all

\section{Further reading}

Ashour, A. and Ibrahim, D. (2018), "Financing the SDGs in Egypt: evaluating the current practices and challenges", A paper presented at: HLPD- 2018: Financing the Sustainable Development Goals in Africa: Strategies for Planning and Resource Mobilization, 10-12 July 2018, Cairo.

Pearl, J. (2003), "Causality: models, reasoning, and inference", Econometric Theory, Vol. 19 No. 04, pp. 675-685 doi: 10.1017/S0266466603004110. 
Appendix

Global economic fluctuations

\begin{tabular}{lcccccr}
\hline Variable & Observations & Mean & Std. dev. & Minimum & Maximum & \\
\hline EXPOR & 26 & 21.97699 & 5.733400 & 13.18385 & 33.04299 & \\
FDI & 26 & 2.278499 & 2.487178 & -0.204532 & 9.343527 & \\
GLOBFLUCT & 26 & 1.619030 & 3.911939 & 0.005058 & 20.22493 & \\
HDI & 26 & 0.622615 & 0.046073 & 0.547000 & 0.691000 & Table A1. \\
ODA & 26 & 3.028885 & 3.915315 & 0.184269 & 14.77508 & Variables descriptive \\
REMITA & 26 & 6.005577 & 2.899833 & 2.856612 & 14.58334 & statistics \\
Source: Eviews 9 & & & & & &
\end{tabular}

Corresponding author

Amira Mohamed Emara can be contacted at: amira.emara@commerce.helwan.edu.eg

For instructions on how to order reprints of this article, please visit our website: www.emeraldgrouppublishing.com/licensing/reprints.htm Or contact us for further details: permissions@emeraldinsight.com 